\title{
PEMANFAATAN LIMBAH EKSTRAKSI ALGINAT DAN SILASE IKAN SEBAGAI BAHAN PUPUK ORGANIK
}

\section{Utilization of Alginate Extraction Waste and Fish Silage as Raw Materials for Organic Fertilizer}

\author{
Jamal Basmal ${ }^{1 *}$, Adwin Widanarto ${ }^{2}$, Rinta Kusumawati ${ }^{1}$ dan Bagus Sediadi Bandol Utomo ${ }^{1}$ \\ ${ }^{1}$ Balai Besar Penelitian dan Pengembangan Pengolahan Produk dan Bioteknologi Kelautan dan Perikanan, \\ JI. K.S. Tubun Petamburan VI, Jakarta Pusat, Indonesia \\ 2 Sekolah Tinggi Perikanan, Indonesia \\ * Korespondensi Penulis: jamalbasmal24@gmail.com
}

Diterima: 18 Maret 2014; Disetujui: 28 November 2014

\begin{abstract}
ABSTRAK
Percobaan pemanfaatan limbah padat ekstraksi alginat dengan tepung silase ikan (tepsil) menjadi bahan pupuk organik telah dilakukan. Perlakuan yang diberikan adalah rasio antara tepung limbah ekstraksi alginat : tepsil $=1: 1 ; 2: 1$ dan 3:1. Sebagai pengikat antara tepung limbah ekstraksi dengan tepsil digunakan pasta Sargassum. Perlakuan rasio limbah padat ekstrasi alginat dengan tepsil mempengaruhi komposisi unsur hara makro dan mikro serta kadar hormon pemacu pertumbuhan dalam bahan pupuk. Ditinjau dari unsur hara makro maka perlakuan yang terbaik ditemukan pada perlakuan $\mathrm{P}_{11}$ yakni satu bagian limbah alginat dan satu bagian tepsil dengan komposisi P 34,56 mg/100g, N 3,01\%, K 1,2 mg/100g, Ca 48,23 mg/100g, C organik $_{21,31 \mathrm{mg} /}$ 100g, Mg 1,41 mg/100 g, kemampuan daya serap air 587,93\% dengan unsur mikro Fe 217,01 ppm, Zn 8 ppm, Cu 0,02 ppm dan nilai hormon pertumbuhan giberelin 82,36 ppm, auksin 67,65 ppm, sitokinin-zeatin 36,86 ppm dan sitokinin-kinetin $28,71 \mathrm{ppm}$. Bahan pupuk yang dihasilkan dapat diproses lebih lanjut menjadi pupuk organik untuk kebutuhan pertanian setelah ditambah dengan unsur hara mikro dan makro dari bahan organik yang lain.
\end{abstract}

KATAKUNCI: limbah padat alginat, tepung silase, unsur hara makro dan mikro, hormon pemacu pertumbuhan

\section{ABSTRACT}

Experiment on the use of solid waste of alginate extraction and fish silage powder into a primary organic fertilizer was carried out. Ratio between solid waste of alginate extraction and fish silage powder were: 1:1; 2:1 and 3:1 respectively, while Sargassum pulp was used as a binder in the production of primary fertilizer. The ratio of silage powder and solid waste of alginate extraction affected the macro and micro nutrients as well as the growth hormone content of each treatment. Based on the macro nutrients content, $P_{11}$ treatment with a ratio of solid waste of alginate and silage powder $1: 1$ was the best shown by the content of $P(34.56 \mathrm{mg} / 100 \mathrm{~g}), \mathrm{N}(3.01 \%), \mathrm{K}(1.2 \mathrm{mg} /$ $100 \mathrm{~g}), \mathrm{Ca}(48.23 \mathrm{mg} / 100 \mathrm{~g}), C_{\text {organik }}(21.31 \mathrm{mg} / 100 \mathrm{~g}), \mathrm{Mg}(1.41 \mathrm{mg} / 100 \mathrm{~g})$, ability to absorp water (587.93\%) and the content of micro nutrients Fe (217,01 ppm), Zn (8 ppm), Cu (0,02 ppm) and growth stimulating hormone giberellin (82.36 ppm), auxin $(67.65 \mathrm{ppm})$, citokynin-zeatin (36.86 ppm) dan citokynin-kinetin (28.71 ppm). The primary fertilizer could be processed into organic fertilizer for agriculture purpose after addition with micro and macro nutrient originated from other organic materials.

\section{KEYWORDS: solid waste of alginate, fish silage, macro and micro-nutrients growth stimulating hormone}

\section{PENDAHULUAN}

Menurut Musnamar (2003) dan Basmal (2010), pupuk organik merupakan pupuk dengan bahan dasar limbah pertanian, limbah proses pengolahan rumput laut dan kotoran hewan dengan jumlah dan jenis unsur hara yang terkandung dalam bahan tersebut secara alami. Pupuk organik merupakan salah satu bahan yang sangat penting dalam upaya memperbaiki kesuburan tanah secara aman, dalam arti produk 
pertanian yang dihasilkan terbebas dari bahan-bahan kimia yang berbahaya bagi kesehatan manusia sehingga aman dikonsumsi. Salah satu jenis limbah proses pengolahan rumput laut yang potensial untuk dibuat pupuk organik adalah limbah pengolahan rumput laut coklat (Sargassum) yang banyak tersebar di perairan Indonesia. Menurut Kadi (2004) di perairan Selat Sunda terdapat 7 jenis rumput laut Sargassum dengan biomas berat basah antara $500-900 \mathrm{~g} / \mathrm{m}^{2}$.

Estimasi limbah padat yang dihasilkan dari proses pengolahan rumput laut Sargassum dapat mencapai $80 \%$ dari berat awal rumput laut yang diproses (Basmal et al., 2012). Limbah padat tersebut kaya akan unsur hara yang diperlukan untuk memacu pertumbuhan tanaman seperti unsur hara makro N-P-K dan $\mathrm{Ca}$, dan unsur hara mikro $\mathrm{Fe}, \mathrm{B}, \mathrm{Ca}, \mathrm{Cu}, \mathrm{C} 1, \mathrm{~K}, \mathrm{Mg}, \mathrm{Mn}, \mathrm{P}$, $\mathrm{S}, \mathrm{Zn}$, dan Boron (B) dengan kisaran kandungan nitrogen $1,00 \%$, fosfor $0,05 \%$; kalium $10,00 \%$; kalsium $1,20 \%$; magnesium $0,80 \%$; sulfur $3,70 \%$; tembaga 5 ppm; besi 1200 ppm; mangan 12 ppm; seng 100 ppm; boron 80 ppm; senyawa organik $50-55 \%$ dan kadar abu 45-50\% (Anon., 2009). Di samping itu, Basmal dan Hidayat (2010) melaporkan hormon pemacu pertumbuhan (ZPT) yang ditemukan dalam rumput laut Sargassum adalah auksin, giberellin, dan sitokinin (zeatin dan kinetin) yang bermanfaat untuk memacu pertumbuhan tanaman. MacCrathy et al. (1990) mengatakan penggunaan ZPT yang tepat akan dapat meningkatkan pertumbuhan tanaman, meningkatkan populasi mikroba tanah dan dapat menekan pengaruh salinitas serta ion logam yang bersifat toksik.

Permasalahan utama dalam pembuatan pupuk organik dari limbah padat rumput laut adalah kekurangan unsur hara makro seperti N-P-K dan Corganik, oleh sebab itu perlu dilakukan kombinasi dengan bahan-bahan lain yang dapat saling melengkapi.

Salah satu produk perikanan yang dapat digunakan untuk meningkatkan unsur hara makro dan mikro limbah ekstraksi alginat sebagai bahan pupuk adalah dengan menambahkan tepung silase ikan yang dibuat dari limbah filet ikan. Silase atau tepung silase (tepsil) merupakan hasil proses fermentasi yang dilakukan baik secara kimiawi dengan penambahan asam, organik atau anorganik maupun secara biologi yang terbuat dari ikan dan atau dari limbah perikanan. Tepsil dapat dimanfaatkan untuk ransum pakan maupun untuk pembuatan pupuk organik karena tepsil kaya akan asam amino, mineral dan vitamin yang sangat bermanfaat untuk memacu pertumbuhan tanaman. Penambahan silase/tepsil dalam pembuatan pupuk organik akan dapat melengkapi unsur hara makro, mikro dan vitamin di dalam pupuk organik tersebut. Prinsip pembuatan tepung silase ikan adalah dengan cara merendam limbah filet ikan dalam larutan asam sehingga bakteri pembusuk tidak dapat hidup dan produk tepung silase ikan dapat bertahan dalam waktu yang cukup lama (Kompiang \& llyas, 1983). Komposisi nutrisi tepung silase ikan dengan bahan pengikat (filler) dedak padi kalau dinyatakan dalam persen berat kering adalah sebagai berikut: kadar protein berkisar antara 24,80-25,51\%, kadar lemak 16,96-18,55 dan serat kasar 8,83-9,75\% (Wulandari, 2000). Sedangkan tepung silase ikan yang menggunakan bahan pengikat pollard memiliki kadar protein, kadar lemak dan serat kasar masing-masing berkisar antara $26,67-27,71 \% ; 3,16-6,04 \%$ dan $7,86-$ $9,42 \%$.

Penelitian ini bertujuan untuk memaksimalkan pemanfaatkan limbah pengolahan rumput laut dan limbah perikanan menjadi bahan pupuk organik yang lebih kaya akan unsur hara makro dan mikro serta hormon pertumbuhan.

\section{BAHAN DAN METODE}

\section{Bahan}

Bahan yang digunakan dalam membuat formulasi pupuk organik dari limbah pengolahan rumput laut adalah limbah ekstraksi Sargassum sp. menjadi sodium alginat. Limbah yang diperoleh tersebut sebelum digunakan dikeringkan terlebih dahulu selanjutnya digiling dengan ukuran 40 mesh. Tepung silase yang digunakan diperoleh dari limbah filet ikan kuniran yang berupa kepala, sisik, tulang dan isi perut yang diperoleh dari pengolah filet ikan kuniran di daerah Eretan Kulon. Sebagai pengikat digunakan pasta rumput laut Sargassum sp.

\section{Metode}

\section{Penyediaan bahan baku limbah rumput laut}

Bahan baku yang digunakan untuk pembuatan bahan pupuk rumput laut adalah limbah hasil pengolahan alginat dari rumput laut Sargassum sp. menggunakan metoda Basmal et al. (2012). Limbah padat yang bercampur dengan tanah diatome dikumpulkan dan dikeringkan menggunakan sinar matahari. Setelah limbah tersebut kering kemudian dilakukan penggilingan dan pengayakan dengan ukuran 40 mesh.

\section{Penyediaan silase limbah ikan kuniran}

Limbah ikan kuniran yang terdiri atas bagian kepala, sisik, tulang dan isi perut direndam dalam $1 \%$ larutan asam khlorida $(\mathrm{HCl})$ dengan rasio $1: 5$ 
selama 1 jam, dibilas untuk menghilangkan kelebihan asam, dikeringkan dan ditepungkan (Basmal, 1995).

\section{Proses pembuatan pasta rumput laut (sebagai pengikat)}

Tepung limbah rumput laut tidak dapat bercampur secara homogen dengan tepung silase, oleh sebab itu diperlukan pengikat. Fungsi pengikat adalah untuk mengikat tepung limbah rumput laut dengan tepung silase, di samping itu juga sebagai penyedia asupan hormon pertumbuhan. Rumput laut Sargassum sp. terlebih dahulu dicuci bersih kemudian ditambahkan natrium karbonat $25 \%$ dari berat rumput laut kering selanjutnya digiling hingga menjadi pasta rumput laut.

\section{Proses pencampuran tepung limbah rumput laut dan tepsil}

Tepung limbah rumput laut dan tepsil dicampur hingga homogen kemudian ditambahkan pengikat sebanyak $16,67 \%$ dari tepsil sambil diaduk hingga rata. Setelah membentuk adonan yang kalis, adonan dicetak menggunakan mesin pelet. Pelet yang terbentuk dikeringkan menggunakan sinar matahari. Metoda pembuatan bahan pupuk dapat dilihat pada Gambar 1.
Perlakuan yang diberikan adalah rasio antara tepung limbah ekstraksi sodium alginat $(\mathrm{kg})$ dan tepung silase $(\mathrm{kg})$ berturut- turut sebagai berikut: $P_{11}=1: 1$; $P_{31}=2: 1$ dan $P_{51}=3: 1$, dengan tiga kali ulangan sedangkan jumlah pengikat/pasta Sargassum sp. yang diberikan untuk setiap perlakuan sebanyak 0,1 $\mathrm{kg}$ atau sebanyak $16,7 \%$ dari tepsil yang digunakan. Untuk menentukan kualitas bahan pupuk limbah rumput laut telah dilakukan analisis hormon pertumbuhan (giberellin, auksin, kinetin, sitokinin) menggunakan $\mathrm{HPLC}$, unsur hara $(\mathrm{N}, \mathrm{P}, \mathrm{K}, \mathrm{N}, \mathrm{Mg}, \mathrm{Mn}$, $\mathrm{K}, \mathrm{Fe}, \mathrm{Zn}, \mathrm{Cu}, \mathrm{Mn}$, Boron) menggunakan AAS, kadar air (BSN, 2006a), kadar abu (BSN, 2006b) dan penentuan nilai $\mathrm{pH}$ menggunakan metode Yunizal et al. (1998).

\section{HASIL DAN PEMBAHASAN}

\section{Karakterisasi Limbah Rumput Laut dan Tepung Silase Ikan}

Limbah rumput laut yang bercampur dengan tanah diatome mempunyai nilai $\mathrm{pH} 10,75$, oleh sebab itu sebelum dipergunakan dinetralkan menggunakan asam fosfat. Tujuan penggunaan asam fosfat di samping untuk penetralan juga dimaksudkan untuk

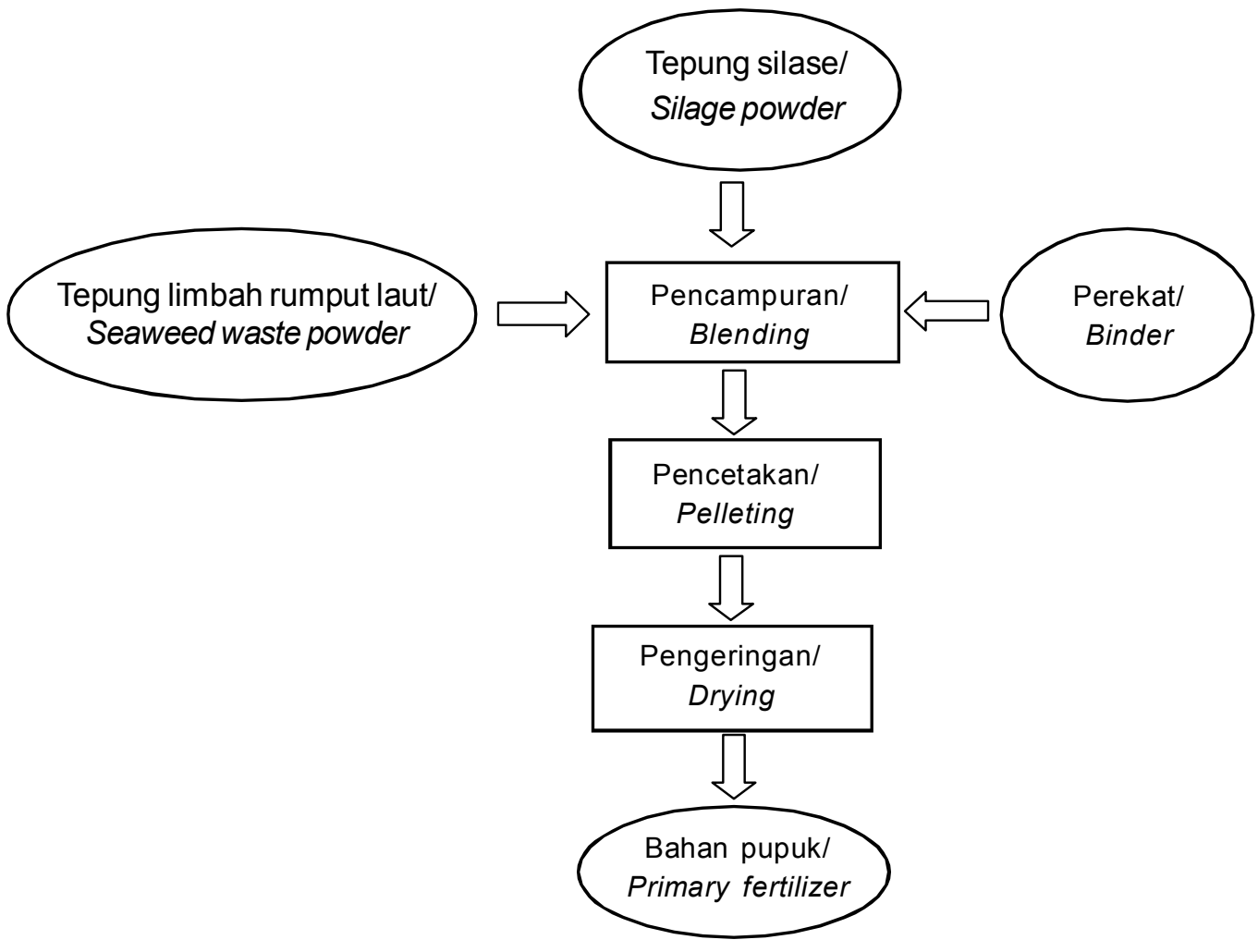

Gambar 1. Diagram pembuatan bahan pupuk.

Figure 1. Process diagram of primary fertilizer production. 
meningkatkan kandungan unsur hara fosfor $(P)$. Limbah rumput laut yang sudah dinetralkan kemudian dikeringkan hingga mencapai kadar air 8,01\% dan kadar abu $79,63 \%$ bk, sedangkan hasil analisis kadar air dan kadar abu Sargassum kering adalah 17,55\% dan $81,76 \%$ bk. Tingginya kadar abu pada Sargassum kering disebabkan masih banyak kotoran yang menempel pada permukaan thallus Sargassum seperti kandungan garam, kapur dan lumpur. Sedangkan kandungan kadar abu yang rendah pada limbah rumput laut kemungkinan disebabkan oleh pemisahan alginat dari bahan lain. Di samping menganalisis kadar air dan kadar abu untuk kedua bahan pupuk tersebut juga dilakukan analisis unsur hara makro, mikro, dan zat pemacu tumbuh (ZPT). Hasil analisis dapat dilihat pada Tabel 1.

Dalam Tabel 1 terlihat bahwa tepsil mempunyai unsur hara makro $\mathrm{Ca}$, C-organik, N-P, dan $\mathrm{P}_{2} \mathrm{O}_{5}$, yang lebih tinggi dibandingkan dengan limbah alginat dan pasta Sargassum. Tingginya unsur hara makro pada tepsil cukup beralasan karena tepsil terbuat dari limbah ikan kuniran yang komposisinya terdiri dari protein dan mineral seperti Ca. Larsen et al. (2000) melaporkan bahwa ikan kaya akan unsur hara Ca dan P, sedangkan Djazuli et al. (1998) melaporkan bahwa tepsil yang terbuat dari limbah ikan lizard mengandung protein sebesar $22 \%$ atau setara dengan unsur hara $\mathrm{N}$ sebesar $3,52 \%$. Selanjutnya Ramasubburayan et al. (2013) melaporkan ikan yang difermentasikan menggunakan asam formiat hingga nilai $\mathrm{pH} 3$ selama 30 hari mempunyai kandungan protein sebesar $36,06 \%$ atau setara dengan unsur hara $N 5,77 \%$. Hasil penelitian menunjukkan unsur hara $\mathrm{N}$ di dalam bahan pupuk berkisar antara 0,21-6,45\% dengan nilai tertinggi ditemukan pada tepsil sebesar $6,45 \%$, limbah padat alginat 0,48\% dan pasta Sargassum 0,21\%. Diharapkan tepsil yang diperoleh ini dapat meningkatkan unsur hara $\mathrm{N}$ dalam formulasi bahan pupuk padat rumput laut. Secara umum unsur hara $\mathrm{N}$ di dalam tanaman termasuk rumput laut merupakan bagian dari sel (organ) dan berfungsi untuk merangsang pertumbuhan, mensintesis asam amino dan protein serta memacu pertumbuhan vegetatif (warna hijau) seperti daun (Syarovy, 2013).

Unsur hara $\mathrm{P}$ di dalam bahan penyusun pupuk limbah rumput laut berkisar antara 0,03-75,44 (mg/

Tabel 1. Karakteristik nutrisi tepung limbah ekstraksi Na-alginat, tepung silase ikan dan pasta Sargassum sp.

Table 1. Nutrition characteristics of Na-alginate extraction waste, fish silage powder and Sargassum sp. paste.

\begin{tabular}{lccc}
\hline \multicolumn{1}{c}{$\begin{array}{c}\text { Parameter/ } \\
\text { Parameters }\end{array}$} & $\begin{array}{c}\text { Limbah Alginat + } \\
\text { Tanah Diatome/ } \\
\text { Alginate Waste + } \\
\text { Diatomaeous Soil }\end{array}$ & $\begin{array}{c}\text { Pasta Sargassum/ } \\
\text { Sargassum Paste }\end{array}$ & $\begin{array}{c}\text { Tepung Silase Ikan/ } \\
\text { Fish Silage Powder }\end{array}$ \\
\hline $\mathrm{P}(\mathrm{mg} / 100 \mathrm{~g})$ & 0.03 & 0.25 & 75.44 \\
$\mathrm{P}_{2} \mathrm{O}_{5}(\mathrm{mg} / 100 \mathrm{~g})$ & & 0.57 & 172.78 \\
$\mathrm{C}-\mathrm{organik}(\mathrm{mg} / 100 \mathrm{~g})$ & 8.35 & 4.58 & 35.94 \\
$\mathrm{~N}(\%)$ & 0.48 & 0.21 & 6.45 \\
$\mathrm{Mg}(\mathrm{mg} / 100 \mathrm{~g})$ & 0.34 & 2.02 & 1.58 \\
$\mathrm{Ca}(\mathrm{mg} / 100 \mathrm{~g})$ & 2.73 & 12.74 & 97.27 \\
$\mathrm{~K}(\mathrm{mg} / 100 \mathrm{~g})$ & 0.18 & 2.12 & 2.12 \\
$\mathrm{Fe}(\mathrm{ppm})$ & 455.49 & 0.21 & 0.21 \\
Zn (ppm) & 16.72 & 0.06 & 0.06 \\
$\mathrm{Cu}(\mathrm{ppm})$ & 2.07 & $<0.01$ & 0.01 \\
$\mathrm{Mn}(\mathrm{ppm})$ & 16.9 & 0.01 & 0.01 \\
$\mathrm{~B}(\mathrm{ppm})$ & $<2$ & $<2$ & $<2$ \\
Auxin (IAA*) $(\mathrm{ppm})$ & 41.22 & 95.77 & 0 \\
Giberellin (ppm) & 38.2 & 128.57 & 0 \\
Zeatin (ppm) & 15.31 & 59.34 & 0 \\
Kinetin (ppm) & 18.01 & 40.13 & 0 \\
\hline
\end{tabular}

* IAA: Indole Acetic Acid 
$100 \mathrm{~g})$ dengan nilai tertinggi pada tepsil sebesar 75,44 (mg/100 g), dan terendah pada limbah padat Sargassum $(0,03 \mathrm{mg} / 100 \mathrm{~g})$. Kandungan P yang tinggi dalam tepsil ini kemungkinan karena bahan yang digunakan adalah limbah ikan kuniran yang hampir $80 \%$ adalah tulang dan sisik. Diketahui bahwa tulang ikan banyak mengandung $\mathrm{Ca}$ dan $\mathrm{P}$ yang terikat dalam bentuk kalsium apatit $\mathrm{Ca}_{5}\left(\mathrm{PO}_{4}\right)_{3}(\mathrm{OH})$. Menurut Kompiang dan Ilyas (1983) dan Djazuli (1998) silase ikan yang dibuat secara kimiawi mengandung nutrisi protein sebesar $73,6 \%$, kalium $1-4 \%$ dan fosfor $0,3-$ $0,9 \%$.

Unsur hara mikro seperti $\mathrm{Fe}, \mathrm{Zn}, \mathrm{Cu}$, dan $\mathrm{Mn}$ ditemukan lebih tinggi dalam limbah alginat dibandingkan dengan pasta Sargassum dan tepsil. Kandungan unsur hara mikro di dalam limbah alginat berkisar antara 2,07-455,49 ppm dengan nilai tertinggi pada unsur hara Fe sebesar 455,49 ppm, kemudian berturut-turut diikuti oleh unsur hara mikro Mn sebesar 16,9 ppm, Zn sebesar 16,72 ppm, dan Cu sebesar 2,07 ppm. Sedangkan di dalam pasta Sargassum dan tepsil kandungan unsur hara berkisar antara $<0,001-$ 0,21 ppm dan nilainya tidak menunjukkan perbedaan yang nyata antara unsur hara mikro pada pasta Sargassum dan tepsil tetapi berbeda sangat nyata dengan limbah alginat. Tingginya unsur hara Fe pada limbah alginat mungkin akibat adanya tanah diatome yang ditambahkan pada saat penyaringan. Pada Tabel 2 dapat dilihat komposisi kimia tanah diatome.

Di dalam limbah alginat dan pasta Sargassum sp. ditemukan kisaran kandungan ZPT Giberellin antara 38,2-128,57 ppm dengan nilai tertinggi pada pasta Sargassum sp. sebesar 128,57 ppm. Hal ini menunjukkan bahwa kombinasi perlakuan panas, penambahan bahan kimia dan penyaringan menggunakan filter press berpengaruh terhadap kandungan giberelin. Richards et al. (2001) berpendapat bahwa giberelin atau asam giberelat (GA), merupakan hormon perangsang pertumbuhan tanaman yang diperoleh dari Gibberella fujikuroi atau Fusarium moniliforme yang berfungsi untuk mematahkan dormansi atau hambatan pertumbuhan tanaman sehingga tanaman dapat tumbuh normal (tidak kerdil) dengan cara mempercepat proses pembelahan sel, meningkatkan pembungaan dan memacu proses perkecambahan biji. Salah satu efek giberelin adalah mendorong terjadinya sintesis enzim dalam biji seperti amilase, protease dan lipase di mana enzim tersebut akan merombak dinding sel endosperm biji dan menghidrolisis pati serta protein yang akan memberikan energi bagi perkembangan embrio di antaranya adalah radikula (calon akar) yang akan mendobrak endosperm, kulit biji atau kulit buah yang membatasi pertumbuhan/perkecambahan biji sehingga biji berkecambah dan berperan pada pemanjangan sel. Selanjutnya dikatakan bahwa giberelin juga berfungsi dalam peningkatan kadar auksin dengan cara memacu pembentukan enzim yang melunakkan dinding sel terutama enzim proteolitik yang akan melepaskan amino triptofan (prekusor/pembentuk auksin) sehingga kadar auksin meningkat, merangsang pembentukan polihidroksi asam sinamat yaitu senyawa yang menghambat kerja enzim indole acetic acid (IAA) oksidase di mana enzim ini merupakan enzim perusak auksin, merangsang terbentuknya enzim a-amilase di mana enzim ini akan menghidrolisis pati sehingga kadar gula dalam sel akan naik dan kandungan air di dalam tanaman meningkat. Adanya peningkatan kandungan air dalam

Tabel 2. Karakteristik kimia dan fisik tanah diatomae

Table 2. Chemical and physical characteristics of diatomaceous soil

\begin{tabular}{cc}
\hline Parameter/Parameters & $\begin{array}{c}\text { Karakteristik Tanah Diatomael } \\
\text { Diatomaceous Soil Characteristics }\end{array}$ \\
\hline Kimia/Chemical & \\
\hline $\mathrm{Al}_{2} \mathrm{O}_{3}$ & $0.0 \%$ \\
$\mathrm{CaO}$ & $1.5 \%$ \\
$\mathrm{Fe}_{2} \mathrm{O}_{3}$ & $3.3 \%$ \\
$\mathrm{Na}_{2} \mathrm{O}+\mathrm{K}_{2} \mathrm{O}$ & $89.6 \%$ \\
$\mathrm{SiO}_{2}$ & \\
\hline Fisik/Physical & \\
\hline Loss on ignition $900{ }^{\circ} \mathrm{C}$ & Maks./Max. 0.2\% \\
Size & $18 \mu \mathrm{mm}$ (granulometric method) \\
$\mathrm{pH}$ & $8.5\left(25{ }^{\circ} \mathrm{C}\right.$ in aqueous suspension) \\
\hline
\end{tabular}

Sumber/Source: Sigma-Aldrich (2014) 
sel akan menyebabkan sel memanjang dan berperan pada proses partenokarpi yang merupakan proses pembentukan buah tanpa adanya fertilisasi.

Kandungan auksin ditemukan berkisar antara 41,22-56,37 ppm dengan nilai tertinggi pada pasta Sargassum. Menurut Andrew et al. (2005) dan Place (2010) auksin berfungsi untuk merangsang pembesaran sel, sintesis DNA kromosom, serta pertumbuhan aksis longitudinal tanaman, merangsang pertumbuhan akar pada setekan atau cangkokan. Selanjutnya dikatakan juga bahwa auksin sering digunakan untuk merangsang pertumbuhan akar dan sebagai bahan aktif sering digunakan dalam persiapan hortikultura komersial terutama untuk akar dan batang. Di samping itu auksin juga dapat digunakan untuk merangsang pembungaan secara seragam, mengatur pembuahan, dan mencegah gugur buah. Golongan auksin antara lain indole acetic acid (IAA), napthalene acetic acid (NAA), 2,4Dichlorophenoxyetanoic acid (2,4-d CPA) dan indole3-butiryc acid (IBA). Yang paling penting dari keluarga auksin adalah indole-3-asam asetat (IAA).

Zeatin dan kinetin merupakan dua komponen ZPT yang tergolong dalam kelompok sitokinin. Dari evaluasi ditemukan bahwa kandungan sitokinin-zeatin 15,31-59,34 ppm dan sitokinin-kinetin 18,01-21,46 dengan nilai tertinggi pada pasta Sargassum. Sakakibara (2006) melaporkan bahwa sitokinin merupakan turunan adenin yang berfungsi untuk merangsang pembelahan sel dan diferensiasi mitosis, disintesis pada ujung akar dan ditranslokasi melalui pembuluh xylem, pematahan dormansi biji pada bijibijian tanaman, pembentukan tunas-tunas baru yang turut dipacu dengan penggunaan sitokinin, penundaan penuaan atau kerusakan pada hasil panenan sehingga lebih awet, menaikkan tingkat mobilitas unsur-unsur dalam tanaman dan sintesis pembentukan protein. Aplikasi sitokinin sering dilakukan untuk merangsang tumbuhnya tunas pada kultur jaringan atau pada tanaman induk, namun sering tidak optimal untuk tanaman dewasa. Golongan ZPT yang termasuk dalam sitokinin adalah kinetin, benziladenin (BA), 2I-P, zeatin, thidiazuron, dan PBA.

Secara keseluruhan kandungan tertinggi ZPT ditemukan pada pasta Sargassum dibandingkan dengan limbah alginat. Rendahnya kandungan ZPT pada limbah alginat kemungkinan disebabkan karena selama proses ekstraksi saat pemisahan alginat dari padatan, sebagian ZPT ikut dalam larutan alginat. Basmal (2010) melaporkan di dalam rumput laut Sargasum terkandung ZPT auksin (IAA) sebesar $112,47 \mathrm{ppm}$, giberelin (GA3) sebesar 132,42 ppm, sitokinin/kinetin sebesar 91,42 ppm, dan zeatin sebesar 77,72 ppm. Merujuk pada hasil penelitian
Basmal (2010) terbukti proses ekstraksi dapat menurunkan kadar ZPT dalam limbah rumput laut.

\section{Karakterisasi Formula Bahan Pupuk Rumput Laut}

\section{Unsur hara makro}

Menurut Barak (1999) yang termasuk unsur hara makro adalah N-P-K, Ca dan Mg serta C-organik. Hasil penelitian menunjukkan bahwa penambahan tepsil di dalam pembuatan bahan pupuk dari limbah alginat berpengaruh sangat nyata terhadap peningkatan unsur hara makro (N-P-K-Ca-Mg dan Corganik). Unsur hara N merupakan unsur hara di dalam tanah yang sangat berperan bagi pertumbuhan tanaman. Perilaku nitrogen dalam tanah sulit diperkirakan karena perpindahannya sangat komplek. Lebih dari 98\% nitrogen dalam tanah tidak tersedia karena terakumulasi dalam bahan organik atau terjerat dalam mineral liat. Pada Tabel 3 terlihat unsur hara $\mathrm{N}$ pada semua perlakuan meningkat dibandingkan dengan limbah alginat dengan rata-rata peningkatan antara $335,42-627,08 \%$ dengan nilai tertinggi ditemukan pada perlakuan $P_{11}$ yakni penambahan tepsil dengan rasio 1 bagian limbah alginat dengan 1 bagian tepsil sebesar 3,01\% kemudian diikuti oleh perlakuan $\mathrm{P}_{31}$ yakni 2 bagian limbah alginat dengan 1 bagian tepsil sebesar $2,18 \%$ dan terendah pada perlakuan $P_{51}$ yakni limbah alginat 3 bagian dengan 1 bagian tepsil sebesar 1,75\%. Dibandingkan dengan standar yang telah ditetapkan oleh Epstein (1965) dalam Barak (1999) dalam Tabel 3, maka perlakuan P11 s/d P51 mempunyai nilai $N$ lebih tinggi dari standar yang sudah ditetapkan. Adanya kandungan protein yang cukup tinggi pada tepsil telah terbukti dapat meningkatkan kandungan nitrogen di dalam pembuatan bahan pupuk dari limbah alginat.

Kandungan unsur hara fosfor $(P)$ pada tepsil berbeda sangat nyata dibandingkan dengan limbah alginat dan pasta Sargassum. Hasil analisis menunjukkan bahwa kandungan unsur hara $\mathrm{P}$ pada tepsil sebesar $75,44 \mathrm{mg} / 100 \mathrm{~g}$, sedangkan pada limbah alginat hanya $0,03 \mathrm{mg} / 100 \mathrm{~g}$ dan $0,25 \mathrm{mg} / 100$ g pada pasta Sargassum (Tabel 3). Jumlah limbah alginat yang ditambahkan dalam formulasi bahan pupuk organik telah mempengaruhi kandungan $\mathrm{P}$ pada setiap perlakuan. Uji kandungan $\mathrm{P}_{2} \mathrm{O}_{5}$ pada setiap perlakuan juga menunjukkan perbedaan (Tabel 3). Peningkatan jumlah limbah alginat yang ditambahkan dalam pembuatan bahan pupuk organik dari limbah rumput laut telah menurunkan kandungan unsur hara $\mathrm{P}$ dan $\mathrm{P}_{2} \mathrm{O}_{5}$ seperti terlihat pada perlakuan $\mathrm{P}_{51}$. Dibandingkan dengan standar kebutuhan tanaman maka semua perlakuan mempunyai kandungan unsur 
Tabel 3. Kandungan unsur hara makro dalam bahan pupuk Table 3. Macronutrients composition of primary fertilizer

\begin{tabular}{lccrrrrr}
\hline $\begin{array}{c}\text { Unsur Hara Makro/ } \\
\text { Macronutrient }\end{array}$ & LAT & PS & Tepsil & $\mathbf{P}_{\mathbf{1 1}}$ & $\mathbf{P}_{\mathbf{3 1}}$ & $\mathbf{P}_{\mathbf{5 1}}$ & $\begin{array}{c}\text { Standar/ } \\
\text { Standard }\end{array}$ \\
\hline $\mathrm{P}(\mathrm{mg} / 100 \mathrm{~g})$ & 0.03 & 0.25 & 75.44 & 34.56 & 24.37 & 18.42 & 200 \\
$\mathrm{P}_{2} \mathrm{O} 5(\mathrm{mg} / 100 \mathrm{~g})$ & - & 0.57 & 172.78 & 82.30 & 55.75 & 42.16 & - \\
$\mathrm{C}-\mathrm{organik}(\mathrm{mg} / 100 \mathrm{~g})$ & 8.35 & 4.58 & 35.94 & 21.31 & 17.13 & 14.98 & - \\
$\mathrm{N}(\%)$ & 0.48 & 0.21 & 6.45 & 3.01 & 2.18 & 1.75 & 1.50 \\
$\mathrm{Mg}(\mathrm{mg} / 100 \mathrm{~g})$ & 0.34 & 2.02 & 1.58 & 1.41 & 1.00 & 0.75 & 200 \\
$\mathrm{Ca}(\mathrm{mg} / 100 \mathrm{~g})$ & 2.73 & 12.74 & 97.27 & 48.23 & 33.55 & 26.03 & 500 \\
$\mathrm{~K}(\mathrm{mg} / 100 \mathrm{~g})$ & 0.18 & 2.12 & 2.12 & 1.20 & 0.87 & 0.70 & 1000 \\
\hline
\end{tabular}

Keterangan/Note: LAT: limbah padat ekstraksi alginat/Solid waste from alginate extraction.

PS: pasta Sargassum/Sargassum paste.

Tepsil: tepung silase ikan/Fish silage powder

*): Requirement of micro and macro nutrients in plant growth (sumber/source:

Epstein, 1965 in Barak, 1999

P11: rasio/ratio = LAT : Tepsil (1:1); P31: rasio/ratio = LAT : Tepsil (2:1);

P51: rasio/ratio $=$ LAT $:$ Tepsil $(3: 1)$.

hara lebih kecil dibandingkan dengan unsur hara yang sudah ditetapkan oleh Barak (1999). Unsur P merupakan komponen penyusun dari beberapa enzim, protein, ATP, RNA, dan DNA yang akan menentukan sifat genetik dari tanaman. Pengaruh terhadap akar adalah membaiknya struktur perakaran sehingga daya serap tanaman terhadap nutrisi menjadi lebih baik. Dampak nyata bila tanaman kekurangan unsur $P$ yakni dimulai dari daun tua menjadi keunguan dan cenderung kelabu, tulang daun muda berwarna hijau gelap, pertumbuhan daun kecil, kerdil, dan akhirnya rontok.

Unsur hara kalium $(\mathrm{K})$ mempunyai nilai terendah dibandingkan dengan unsur hara makro lainnya di dalam formulasi bahan pupuk. Jumlah kandungan unsur hara K pada tepsil dan pasta Sargassum tidak berbeda nyata yakni sebesar $2,12 \mathrm{mg} / 100 \mathrm{~g}$ tetapi berbeda nyata dengan limbah alginat (Tabel 3). Kandungan K antara pasta Sargassum dan limbah padat ekstraksi alginat berbeda nyata yakni proses ekstraksi alginat telah menyebabkan terjadinya penurunan kandungan $\mathrm{K}$ dari $2,12 \mathrm{mg} / 100 \mathrm{~g}$ menjadi $0,18 \mathrm{mg} / 100 \mathrm{~g}$ sehingga dalam formulasi pembuatan bahan pupuk, terjadi penurunan unsur hara $\mathrm{K}$ pada semua perlakuan yang diberikan. Menurut Junowati dan Pitono (1998) dan Ruhnayat (2007) unsur K diperlukan untuk pengaturan proses fisiologi tanaman seperti fotosintetis, akumulasi, translokasi, transportasi karbohidrat, membuka dan menutupnya stomata, atau mengatur distribusi air dalam jaringan dan sel. Kekurangan unsur K telah menyebabkan daun seperti terbakar dan akhirnya gugur dan bunga mudah rontok dan gugur.
Unsur hara Ca dalam formulasi bahan pupuk limbah rumput laut berkisar antara 26,03-48,23 mg/100g dengan nilai tertinggi ditemukan pada perlakuan $P_{11}$ dan terendah pada $P_{51}$. Tingginya kandungan unsur hara Ca dalam perlakuan $\mathrm{P}_{11}$ disebabkan oleh penambahan tepsil karena tepsil banyak mengandung $\mathrm{Ca}$. Hasil analisis kandungan Ca dari tiga jenis bahan pakan yang diformulasikan menunjukkan perbedaan yang sangat nyata yakni pada tepsil sebesar 97,27 $\mathrm{mg} / 100 \mathrm{~g}$, sedangkan dalam limbah alginat dan pasta Sargassum berturut turut sebesar 2,73 dan $12,74 \mathrm{mg} /$ $100 \mathrm{~g}$. Adanya pencampuran yang sempurna dalam pembuatan bahan pupuk menyebabkan kandungan Ca di dalam setiap perlakuan beda sangat nyata. Pada perlakuan $\mathrm{P}_{11}$ jumlah unsur hara $\mathrm{Ca}$ lebih tinggi dibandingkan dengan perlakuan $\mathrm{P}_{31}$ dan $\mathrm{P}_{51}$. Epstein (1965) dalam Barak (1999) menyebutkan dalam standar kebutuhan unsur hara Ca tanaman adalah sebesar $500 \mathrm{mg} / 100 \mathrm{~g}$, sedangkan dalam penelitian ini kadar $\mathrm{Ca}$ untuk semua perlakuan ditemukan di bahwa standar yang telah ditentukan. Menurut Junowati dan Pitono (1998) unsur Ca selain dibutuhkan relatif lebih banyak untuk pertumbuhan tanaman adas juga diperlukan untuk meningkatkan nilai $\mathrm{pH}$ tanah masam. Unsur hara $\mathrm{Ca}$ di dalam tanaman berperan dalam proses pembelahan dan perpanjangan sel, dan mengatur distribusi hasil fotosintesis.

Unsur hara Mg yang juga termasuk dalam unsur makro berkisar antara $0,75-1,41 \mathrm{mg} / 100 \mathrm{~g}$. Nilai tertinggi ditemukan pada perlakuan $\mathrm{P}_{11}(1,41 \mathrm{mg} / 100$ g) kemudian diikuti oleh perlakuan $P_{31}(1 \mathrm{mg} / 100 \mathrm{~g})$ dan perlakuan $\mathrm{P}_{51}(0,75 \mathrm{mg} / 100 \mathrm{~g})$. Tingginya unsur 
hara $\mathrm{Mg}$ dalam perlakuan $\mathrm{P}_{11}$ dibandingkan dengan perlakuan $\mathrm{P}_{31}$ dan $\mathrm{P}_{51}$ dipengaruhi oleh penambahan tepsil yang lebih banyak daripada perlakuan $P_{31}$ dan $P_{51}$. Sedangkan pada perlakuan $P_{51}$ penurunan unsur hara $\mathrm{Mg}$ disebabkan oleh penambahan limbah alginat yang lebih besar dibandingkan dengan perlakuan $P_{11}$. Epstein (1965) dalam Barak (1999) menyatakan kebutuhan/ akumulasi unsur hara Mg dalam tanaman sebesar 200 ppm sedangkan pada semua perlakuan kandungan unsur hara Mg hanya berkisar antara 7,515,8 ppm. Bila merujuk pada Permentan nomor $70 /$ Permentan/SR.140/10/2011 tentang pupuk organik, pupuk hayati dan pembenahan tanah tidak mensyaratkan adanya unsur hara dalam pupuk organik granula. Magnesium berfungsi sebagai aktivator dalam transportasi energi ke beberapa enzim di dalam tanaman. Unsur ini sangat dominan keberadaannya di daun, terutama untuk ketersediaan klorofil, oleh sebab itu unsur Mg dalam tanah maupun dalam pupuk harus tersedia yang akan diangkut ke dalam daun. Pada Tabel 3 dapat dilihat bahwa unsur hara $\mathrm{Mg}$ di dalam limbah alginat lebih kecil dari tepsil.

Unsur hara $\mathrm{C}_{\text {organik }}$ dalam perlakuan yang diberikan berkisar antara 14,98-21,31 mg/100g. Adanya penambahan kandungan $\mathrm{C}_{\text {organik }}$ dalam semua perlakuan disebabkan oleh adanya penambahan tepsil dalam pembuatan bahan pupuk limbah alginat. Penambahan jumlah limbah alginat yang berbeda telah menyebabkan kandungan $\mathrm{C}_{\text {organik }}$ juga berbeda dengan nilai tertinggi ditemukan pada perlakuan $P_{11}$ $(21,31 \mathrm{mg} / 100 \mathrm{~g})$ dan terendah pada perlakuan $P_{51}$ $(14,98 \mathrm{mg} / 100 \mathrm{~g})$. Kandungan $\mathrm{C}_{\text {organik }}$ pada tepsil sebesar 35,94 mg/100 g jauh lebih tinggi dibandingkan dengan limbah alginat maupun pasta Sargassum (Tabel 3). Penambahan tepsil telah mempengaruhi kandungan $\mathrm{C}_{\text {organik }}$ dalam setiap perlakuan yang diberikan. Semakin tinggi limbah rumput laut yang ditambahkan semakin menurun kandungan unsur hara makro dalam bahan pupuk limbah rumput laut. Permentan nomor 70/Permentan/SR.140/10/2011 tentang pupuk organik, pupuk hayati dan pembenahan tanah mensyaratkan unsur $\mathrm{C}_{\text {organik }}$ minimal $15 \%$.

\section{Unsur hara mikro}

Secara umum kandungan unsur hara mikro di dalam semua perlakuan lebih rendah dibandingkan dengan unsur hara mikro yang ada di dalam limbah alginat. Kandungan Fe berkisar antara 217, 01-333,34 ppm (Tabel 4) dengan perlakuan $P_{51}$ tertinggi dibandingkan dengan perlakuan $\mathrm{P}_{31}$ dan $\mathrm{P}_{11}$. Epstein (1965) dalam Barak (1999) menyebutkan kebutuhan unsur Fe dalam tanaman sebesar 100 ppm. Tingginya kandungan Fe dalam semua perlakuan dibandingkan standar telah diperoleh dari limbah alginat. Adanya penambahan filter aids/tanah diatome pada saat pemisahan alginat dari limbahnya juga berperan besar dalam peningkatan unsur hara Fe dalam semua perlakuan karena jumlah tanah diatome yang ditambahkan adalah sebanyak 2-3\% dari jumlah bubur alginat. Peran Fe dalam tanaman membantu proses pembentukan protein dan sebagai katalisator pembentukan klorofil namun pemberian pupuk dengan kandungan $\mathrm{Fe}$ berlebihan dapat menyebabkan terjadinya nekrosis yang ditandai dengan munculnya bintik-bintik hitam pada daun oleh sebab itu diperlukan dosis yang tetap untuk tanaman tertentu.

Tabel 4. Kandungan unsur hara mikro bahan pupuk

Table 4. Micronutrien content in primary fertilizer

\begin{tabular}{crrrrrrc}
\hline $\begin{array}{c}\text { Unsur Hara Makrol } \\
\text { Macronutrient }\end{array}$ & LAT & PS & Tepsil & $\mathbf{P}_{\mathbf{1 1}}$ & $\mathbf{P}_{\mathbf{3 1}}$ & $\mathbf{P}_{\mathbf{5 1}}$ & $\begin{array}{c}\text { Standarl } \\
\text { Standard }^{*}\end{array}$ \\
\hline Fe (ppm) & 455.49 & 0.21 & 0.21 & 217.01 & 293.94 & 333.34 & 100 \\
Zn (ppm) & 16.72 & 0.06 & 0.06 & 8.00 & 10.80 & 12.25 & 20 \\
$\mathrm{Cu}(\mathrm{ppm})$ & 2.07 & $<0.01$ & $<0.01$ & 0.02 & $<0.01$ & 0.03 & 6 \\
$\mathrm{Mn}(\mathrm{ppm})$ & 16.90 & 0.01 & 0.01 & 8.05 & 10.91 & 12.37 & 50 \\
$\mathrm{~B}(\mathrm{ppm})$ & $<2$ & $<2$ & $<2$ & $<2$ & $<2$ & $<2$ & 20 \\
\hline
\end{tabular}

Keterangan/Note: LAT: limbah padat ekstraksi alginat/Solid waste from alginate extraction.

PS: pasta Sargassum/Sargassum paste.

Tepsil: tepung silase ikan/Fish silage powder

*): Requirement of micro and macro nutrients in plant growth (sumber/source:

Epstein, 1965 in Barak, 1999)

P11: rasio/ratio = LAT $:$ Tepsil (1:1); P31: rasio/ratio = LAT $:$ Tepsil (2:1);

P51: rasio/ratio $=$ LAT $:$ Tepsil $(3: 1)$. 
Unsur hara $\mathrm{Zn}$ dalam semua perlakuan berkisar antara 8,0-12,25 ppm (Tabel 4) dengan nilai tertinggi ditemukan pada perlakuan $\mathrm{P}_{51}$ kemudian dikuti oleh perlakuan $\mathrm{P}_{21}$ dan $\mathrm{P}_{11}$ (Table 4). Peningkatan unsur hara mikro Zn sebagian besar diperoleh dari limbah alginat. Penambahan tepsil tidak mempengaruhi peningkatan kandungan unsur hara $\mathrm{Zn}$, hal ini disebabkan kandungan unsur hara $\mathrm{Zn}$ dalam tepsil tidak berbeda nyata dengan pasta Sargassum $(0,06$ ppm) yang relatif lebih kecil dibandingkan dengan limbah alginat. Epstein (1965) dalam Barak (1999) menyatakan kebutuhan $\mathrm{Zn}$ dalam tanaman yang diserap baik dari dalam tanah maupun yang diberikan melalui pupuk adalah sebanyak 20 ppm. Kandungan $\mathrm{Zn}$ dalam setiap perlakuan masih lebih kecil dari standar yang telah ditetapkan. Peran $\mathrm{Zn}$ dalam tanaman hampir sama dengan $\mathrm{Mn}$ dan $\mathrm{Mg}$ yakni berperan dalam aktivator enzim, pembentukan klorofil dan membantu proses fotosintesis. Kekurangan asupan $\mathrm{Zn}$ akan mengakibatkan pertumbuhan lambat, jarak antar buku pendek, daun kerdil dan mengkerut, atau menggulung di satu sisi lalu disusul dengan kerontokan, bakal buah menguning, terbuka, dan akhirnya gugur. Buah pun akan lebih lemas sehingga buah yang seharusnya lurus menjadi membengkok. Kelebihan $\mathrm{Zn}$ dalam tanah tidak mempengaruhi pertumbuhan tanaman.

Tembaga diserap tanaman dalam bentuk ion $\mathrm{Cu}^{2+}$ atau $\mathrm{Cu}^{3+}$, unsur ini beperan sebagai aktfiator enzim dalam proses penyimpanan cadangan makanan, katalisator dalam proses pernapasan dan perombakan karbohidrat dan sebagai salah satu elemen dalam proses pembentukan vitamin A dan secara tidak langsung berperan dalam pembentukan klorofil. Hasil analisis kandungan Cu pada semua perlakuan yang diberikan berkisar antara $0,01-0,03$ ppm dengan nilai tertinggi pada perlakuan $\mathrm{P}_{51}$, dan terendah pada perlakuan $\mathrm{P}_{31}$. Peningkatan kandungan $\mathrm{Cu}$ lebih banyak dipengaruhi oleh penambahan limbah alginat dibandingkan dengan penambahan tepsil dan pasta Sargassum. Ketersediaan Cu pada tanah yang normal 0,1-4,0 ppm dan kebutuhan normal tanaman berkisar antara 5-20 ppm (Anon., 2012). Selanjutnya dikatakan bahwa kekurangan Cu pada padi ditunjukan lewat daun muda yang memutih dengan ujungnya yang mengering.

Mangan $(\mathrm{Mn})$ merupakan unsur mikro yang dibutuhkan tanaman dalam jumlah yang tidak terlalu banyak dan diperlukan untuk sintesa klorofil. Selain itu Mn berperan sebagai koenzim, sebagai aktivator beberapa enzim respirasi dalam reaksi metabolisme nitrogen dan fotosintesis. Di samping itu, juga diperlukan untuk mengaktifkan nitrat reduktase sehingga tumbuhan yang mengalami kekurangan mangan memerlukan sumber $\mathrm{N}$ dalam bentuk $\mathrm{NH}_{4}^{+}$.
Hasil penelitian menunjukkan kandungan Mn dalam semua perlakuan berkisar antara 8,05-12,37 ppm dengan perlakuan $P_{51}$ yang mempunyai kandungan Mn tertinggi dibandingkan dengan perlakuan lainnya. Peningkatan kandungan unsur hara mikro Mn lebih dipengaruhi oleh rasio limbah alginat yang ditambahkan pada setiap perlakuan. Pada perlakuan $\mathrm{P}_{51}$ jumlah limbah alginat yang ditambahkan tiga bagian dan satu bagian tepsil, sedangkan pada perlakuan $\mathrm{P}_{11}$ limbah alginat satu bagian dan tepsil satu bagian. Jika dilihat dari formulasinya peningkatan unsur hara mikro Mn dipengaruhi oleh peningkatan jumlah limbah alginat yang ditambahkan. Namun jika dibandingkan dengan kebutuhan $\mathrm{Mn}$ dalam pertumbuhan tanaman masih lebih kecil. Telah diketahui bahwa unsur Mn tidak hanya tergantung pada asupan dari pupuk yang diberikan tetapi juga diambil dari dalam tanah. Pupuk hanya berfungsi sebagai supplement dalam memacu pertumbuhan tanaman. Untuk itu Epstein (1965) dalam Barak (1999) telah menetapkan bahwa kebutuhan akumulasi $\mathrm{Mn}$ dalam pertumbuhan sebesar $50 \mathrm{ppm}$ yang diambil dari dalam tanah dan pemberian asupan pupuk.

\section{Zat Pemacu Tumbuh (ZPT)}

Zat pemacu tumbuh (ZPT) hanya ditemukan dalam rumput laut Sargassum sp. dan limbah padat pemisahan alginat. Di dalam formulasi bahan pupuk telah ditemukan jenis ZPT yaitu : giberelin, auksin, dan sitokinin (zeatin dan kinetin).

Hasil analisis dalam Tabel 5 menunjukkan bahwa kandungan setiap ZPT untuk setiap perlakuan tidak sama. Nilai ZPT tertinggi ditemukan pada perlakuan $P_{51}$ dengan rasio limbah alginat dan tepsil $=3: 1$, sedangkan nilai terendah pada perlakuan $\mathrm{P}_{31}$ dengan rasio antara limbah alginat dan tepsil adalah $2: 1$, kecuali kadar giberelin. Peningkatan ZPT untuk semua perlakuan dipengaruhi oleh jumlah limbah alginat yang diformulasikan dalam pembuatan pupuk limbah rumput laut.

\section{Proksimat Analisis}

Kadar abu untuk semua perlakuan berkisar antara $50,58-58,31 \%$, (Tabel 6 ) dengan nilai tertinggi pada perlakuan $P_{51}$ kemudian diikuti oleh perlakuan $P_{31}$ dan $P_{11}$. Peningkatan jumlah limbah rumput laut di dalam perlakuan juga berarti peningkatan jumlah tanah diatome. Dalam proses ekstraksi jumlah tanah diatome yang ditambahkan berkisar antara 2-3\%. Telah diketahui bahwa tanah diatome mengandung mineral yang sangat tinggi (Tabel 2) yakni kandungan $\mathrm{SiO}_{2}$ sebesar $89,6 \%$ (Sigma-Aldrich, 2014). Penambahan kadar abu untuk semua perlakuan di samping diperoleh dari tanah diatome juga dari tepsil. 
Tabel 5. Zat pemacu tumbuh (ZPT) dalam bahan pupuk

Table 5. Growth stimulating hormone in primary fertilizer

\begin{tabular}{lccc}
\hline \multirow{2}{*}{$\begin{array}{c}\text { Hormon Pemacu Pertumbuhan/ } \\
\text { Growth Stimulating Hormone }\end{array}$} & \multicolumn{3}{c}{ Perlakuan/Treatment } \\
\cline { 2 - 4 } & P11 & P31 & P51 \\
\hline Auxins $(\mathrm{mg} / \mathrm{kg})$ & 67.65 & 62.67 & 80.14 \\
Zeatin $(\mathrm{mg} / \mathrm{kg})$ & 36.86 & 35.36 & 41.85 \\
Kinetin $(\mathrm{mg} / \mathrm{kg})$ & 28.71 & 26.51 & 34.14 \\
\hline
\end{tabular}

Keterangan/Note: P11: Rasio limbah rumput laut : tepsil/Ratio of seaweed waste : silage powder: $1: 1$ P31: Rasio limbah rumput laut : tepsil/Ratio of seaweed waste : silage powder. $2: 1$ P51: Rasio limbah rumput laut : tepsil/Ratio of seaweed waste : silage powder. $3: 1$

Hasil analisis kadar abu tepsil adalah sebesar 31,66\% bk, sedangkan limbah alginat sebesar 79,63\% bk.

Nilai $\mathrm{pH}$ untuk semua perlakuan berkisar antara 9,10-9,73 (Tabel 6) dengan nilai tertinggi pada perlakuan $\mathrm{P}_{51}$ kemudian diikuti oleh perlakuan $\mathrm{P}_{31}$ dan $\mathrm{P}_{11}$. Nilai pH semua perlakuan sangat dipengaruhi oleh nilai $\mathrm{pH}$ tepsil dan limbah alginat. Hasil analisis menunjukkan bahwa nilai $\mathrm{pH}$ tepsil 4,84 dan limbah alginat 10,75 (Tabel 7). Pada perlakuan $\mathrm{P}_{51}$ nilai $\mathrm{pH}$ 9,73 sedikit terjadi penurunan dengan penambahan tepsil. Jumlah tepsil yang ditambahkan dalam perlakuan $\mathrm{P}_{51}$ adalah sepertiga dari berat limbah alginat, sedangkan pada perlakuan $\mathrm{P}_{31}$ jumlah tepsil yang ditambahkan setengah dari berat limbah alginat.

Di dalam bahan pupuk rumput laut, di samping unsur hara makro, mikro dan ZPT juga perlu diperhitungkan kemampuan daya serap air atau kemampuan pupuk untuk mengikat air. Hal ini penting untuk tanaman karena tanaman akan tumbuh subur bila asupan nutrisinya baik dan tingkat kelembabannya cukup. Hasil analisis daya serap air yang tinggi ditemukan pada perlakuan $\mathrm{P}_{11}(587,93 \%)$, kemudian diikuti oleh perlakuan $\mathrm{P}_{31}(524,36 \%)$ dan terkecil perlakuan $\mathrm{P}_{51}(514,59 \%)$ (Tabel 6). Kemampuan daya serap air sangat dipengaruhi oleh komposisi penyusun bahan pupuk. Pada perlakuan $P_{11}$ komposisinya adalah satu bagian limbah alginat dan satu bagian tepsil. Adanya komposisi bahan pupuk yang berimbang telah berimbas pada peningkatan daya serap air, sedangkan pada perlakuan $\mathrm{P}_{31}$ dengan komposis bahan penyusun pupuk 2 bagian limbah alginat dengan 1 bagian tepsil telah menyebabkan penurunan kemampuan menyerap air. Semakin tidak seimbang rasio antara tepsil dan limbah alginat yang dicampurkan dalam pembuatan bahan pupuk limbah rumput laut akan semakin menurun kemampuannya untuk menyerap air seperti yang terjadi pada perlakuan $P_{51}$ di mana rasio antara tepsil berbanding limbah

Tabel 6. Kadar air, abu dan nilai pH bahan pupuk

Table 6. Moisture content, ash content and $\mathrm{pH}$ of primary fertilizer

\begin{tabular}{lrrr}
\hline \multirow{2}{*}{ Parameter/Parameters } & \multicolumn{3}{c}{ Perlakuan/Treatments } \\
\cline { 2 - 4 } & \multicolumn{1}{c}{ P11 } & \multicolumn{1}{c}{ P31 } & \multicolumn{1}{c}{ P51 } \\
\hline Kadar air/Moisture content (\%bb) & 5.91 & 6.80 & 6.41 \\
Kadar abu/Ash content (\%bk) & 50.58 & 55.05 & 58.31 \\
Nilai pH/pH value & 9.10 & 9.46 & 9.73 \\
Kemampuan daya serap air/Water absorption (\%) & 587.93 & 524.36 & 514.59 \\
Berat basah pupuk/Wet weight (g) & $1,215.00$ & $1,180.00$ & $1,180.00$ \\
Berat kering pupuk/Dry weight (g) & $1,143.19$ & $1,099.76$ & $1,104.36$ \\
Rendemen/Yield (\%) & 67.50 & 65.30 & 65.30 \\
\hline
\end{tabular}

Keterangan/Note: P11: Rasio limbah rumput laut $:$ tepsil/Ratio of seaweed waste $:$ silage powder. $=1: 1$ P31: Rasio limbah rumput laut: tepsil/Ratio of seaweed waste : silage powder: $=2: 1$ P51: Rasio limbah rumput laut: tepsil/Ratio of seaweed waste : silage powder: $=3: 1$ 
Tabel 7. Kadar air, abu dan $\mathrm{pH}$ tepung silase ikan dan limbah alginat

Table 7. Moisture content, ash content and $\mathrm{pH}$ of fish silage and alginate extraction waste

\begin{tabular}{lcc}
\hline \multirow{2}{*}{ Jenis Analisa/Type of Analysis } & \multicolumn{2}{c}{ Jenis Bahan Baku/Raw Materials } \\
\cline { 2 - 3 } & Tepsil* $^{*}$ LAT* $^{*}$ & 8.01 \\
\hline Kadar air/Moisture content (\%) bb/wb & 9.63 & 79.63 \\
Kadar abu/Ash content $(\%)$ bk/db & 31.66 & 10.75 \\
Nilai pH/pH value & 4.84 & \\
\hline Keterangan/Note: * Tepsil: tepung silase/fish silage, & \\
& $*$ *AT: limbah ekstraksi alginat/alginate extraction waste &
\end{tabular}

alginat adalah tiga dibanding satu yang menghasilkan daya serap air sebesar $514,59 \%$.

Berdasarkan hasil analisis, rendemen yang diperoleh berkisar antara $65,30-67,50 \%$ dengan nilai tertinggi pada perlakuan $\mathrm{P}_{11}$ sedangkan antara perlakuan $\mathrm{P}_{31}$ dan $\mathrm{P}_{51}$ tidak berbeda nyata $(65,30 \%)$. Faktor yang mempengaruhi rendemen antara lain kadar air masing-masing bahan pupuk dan sifat/ karakteristik bahan pupuk (rasio bahan yang digunakan dalam formulasi). Hasil perhitungan berat kering bahan pupuk pada perlakuan $\mathrm{P}_{11}$ sebesar $1.143,19 \mathrm{~g}, \mathrm{P}_{31}$ sebesar $1.099,76 \mathrm{~g}$ dan $\mathrm{P}_{51}$ sebesar $1.104,36 \mathrm{~g}$. Perbedaan kadar air telah mempengaruhi rendemen yang diperoleh yakni pada perlakuan $\mathrm{P}_{11}$ nilai kadar air lebih kecil jika dibandingkan dengan perlakuan $P_{31}$ dan $P_{51}$ sedangkan perbedaan kadar air $P_{31}$ dan $P_{51}$ tidak memberikan perbedaan nyata pada rendemennya.

\section{KESIMPULAN DAN SARAN}

\section{Kesimpulan}

Pencampuran antara limbah alginat dengan tepsil menggunakan pasta Sargassum sebagai binder dapat dimanfaatkan sebagai bahan pupuk organik. Penambahan tepsil akan mempengaruhi unsur hara makro seperti N-P-K-Ca- $\mathrm{C}_{\text {organik }}$ dalam pembuatan bahan pupuk dari kombinasi tepung limbah alginat dengan tepung silase. Komposisi unsur hara mikro dan ZPT lebih dipengaruhi oleh rasio limbah alginat yang digunakan. Berdasarkan penambahan tepung silase yang kaya akan unsur hara makro (N-P-K) maka perlakuan $P_{11}$ yakni limbah alginat satu bagian dan satu bagian tepsil merupakan hasil yang terbaik ditinjau dari unsur hara $\mathrm{P}(34,56 \mathrm{mg} / 100 \mathrm{~g}), \mathrm{N}(3,01 \%)$, $\mathrm{K}(1,2 \mathrm{mg} / 100 \mathrm{~g})$, Ca $(48,23 \mathrm{mg} / 100 \mathrm{~g}), \mathrm{C}_{\text {organik }}$
(21,31 mg/100 g), Mg (1,41 mg/100 g) dan kemampuan daya serap air sebesar $587,93 \%$ dengan unsur mikro $\mathrm{Fe}(217,01 \mathrm{ppm}), \mathrm{Zn}(8 \mathrm{ppm}), \mathrm{Cu}(0,02 \mathrm{ppm})$ dan nilai hormon pertumbuhan giberelin $(82,36 \mathrm{ppm})$, auksin $(67,65 \mathrm{ppm})$, sitokinin-zeatin $(36,86 \mathrm{ppm})$, dan sitokinin-kinetin (28,71 ppm).

\section{Saran}

Pembuatan bahan pupuk organik dari kombinasi limbah pengolahan alginat dengan tepung silase menghasilkan bahan pupuk dengan jumlah unsur hara makro dan mikro yang masih di bawah standar yang telah dipersyaratkan oleh Epstein dalam Barak (1999). Oleh sebab itu agar dapat dimanfaatkan sebagai pupuk organik yang memenuhi kebutuhan asupan makro dan mikro pada tanaman tertentu maka perlu menambahkan unsur hara makro dan mikro dari bahan organik lain.

\section{DAFTAR PUSTAKA}

Andrew, W., Woodward, \& Bartel, B. (2005). Auxin: Regulation, Action, and Interaction. Invited Review. Annals of Botany. 95: 707-735, www.aob. oupjournals.org.

Anonim. (2009). Pupuk organik, pupuk hayati dan pupuk kimia. http://isroi.wordpress.com/2008/02/26/pupukorganik-pupuk-hayati-dan-pupuk-kimia/.

Anonim. (2012). Fungsi unsur hara mikro terhadap tumbuhan. http://bebbeib15012012.blogspot.com/ 2012/04/fungsi-unsur-hara-mikro-terhadap.html. Diakses pada tanggal 7 Desember 2014.

Barak. P. (1999). Essestial elements for plant growth. Macronutrients and micronutrents. http://soils.wisc. edu/facstaff/barak/soilscience326/nitrogen.htm

Basmal. J., Tri Murtini, J., Tazwir, \& Indriati, N. (1995). Pengaruh konsentrasi asam formiat pada pembuatan silase dari limbah ikan pari. Jurnal Penelitian Pasca Panen Perikanan 84: 1-7. 
Basmal. J. (2010). Teknologi pembuatan pupuk cair kombinasi hidrolisat rumput Laut Sargassum sp. dan limbah perikanan. Squalen Buletin Pascapanen dan Bioteknologi Kelautan dan Perikanan. 5(2): 59-66.

Basmal, J. \& Hidayat, W. (2010). Pengaruh penambahan silase ikan terhadap pupuk organik cair rumput laut Sargassum sp. Prosiding Seminar Nasional Pengolahan Produk dan Bioteknologi Kelautan dan Perikanan-II, Jakarta. p. 175-180.

Basmal, J., Utomo, B.S.B., Tazwir, Murdinah, Wikanta, T., Marraskuranto, E., \& Kusumawati, R. (2012). Pengembangan Produksi Alginat Skala Pilot dan Pemanfaatannya dalam Produk Pangan dan Non Pangan. Laporan Teknis. Balai Besar Penelitian dan Pengembangan Pengolahan Produk dan Bioteknologi Kelautan dan Perikanan. 38 pp.

[BSN] Badan Standarisasi Nasional. (2006a). Cara Uji Kimia-Bagian 2 : Penetuan Kadar Air pada Produk Perikanan. No. SNI 01-2354.2-2006. Badan Standarisasi Nasional. 4 pp.

[BSN] Badan Standarisasi Nasional. (2006b). Cara Uji Kimia-Bagian 1 : Penentuan Kadar Abu pada Produk Perikanan. No. SNI 01-2354.1-2006. Badan Standarisasi Nasional. 4 pp.

Djazuli, N., Sunarya, \& Budiyanto, D. (1998). Utilization of fish waste for fish silage powder and its application as feed for chiken and fish culture. National Center for Quality Control and Processing Technology Development, Directorate General of Fisheries. www.apfic.org/Archive/symposia/1998/15.pdf.

Junowati, M. \& Pitono, J. (1998). Pengaruh pupuk P dan $\mathrm{K}$ terhadap pertumbuhan tanaman adas. Warta Tumbuhan Obat. Balittro. 4(1): 27-28.

Kadi. A. (2004). Potensi rumput laut dibeberapa perairan pantai Indonesia. Oseana. XXIX(4): 25-36.

Kompiang, I.P. \& Ilyas, S. (1983). Silase Ikan: Pengolahan, Penggunaan, dan Prospeknya di Indonesia Jurnal Litbang Pertanian. Balai Penelitian Ternak Ciawi, Bogor.

Larsen, T., Thilsted, S.H., Kongsbak, K., \& Hansen, M. (2000). Whole small fish as a rich calcium source. British Journal of Nutrition. 83(2): 191-196.

MacCarthy, P., Clapp, C.E., Malcom, R.L., and Bloom, P.R. (1990). Humic Substances in Soil and Crop Science. Selected Readings, American Society of America, Inc. Madison, Wiscansin, USA.
Musnamar. (2003). Pupuk Organik (Cair dan Padat, Pembuatan Aplikasi). Penebar Swadaya, Jakarta.

Place, M. (2010). Auxin the functions, effects, and applications of a plant growth hormone. Article written by Michael Place using information from the text and lectures of Horticulture 210, instructed by Dr. Chiwon Lee at North Dakota State University. http:// www.ndsu.edu/pubweb/chiwonlee/p/sc211/ student\%20papers/articles00/mplace/mplace.htm.

Ramasubburayan, Iyapparaj, R.P., Subhashini, K.J., Chandran, M.N.A., Palavesam \& Immanue, G. (2013). Characterization and nutritional quality of formic acid silage developed from marine fishery waste and their potential utilization as feed stuff for common carp cyprinus carpio fingerlings. Turkish Journal of Fisheries and Aquatic Sciences. 13: 281-289

Richards, D., King, K.E., Ait-ali, T., \& Harberd, N.P. (2001). A Molecular Genetic Analysis of Gibberellin Signaling. Annu. Rev. Plant Physiol. Plant Mol. Biol. 52: 67-88

Ruhnayat, A. (2007). Penentuan kebuthan pokok unsure hara $\mathrm{N}, \mathrm{P}, \mathrm{K}$ untuk pertumbuhan tanaman panili (Vanilla planifolia Andrews). Bul. Littro. XVIII(1): 4959

Sakakibara, H. (2006). Cytokinins: Activity, Biosynthesis, and Translocation. Annu. Rev. Plant Biol. 2006.57:431-449. Downloaded from arjournals. annualreviews.org. p. 22.

Sigma-Aldrich. (2014). Properties of diatomeous earth. http://www.sigmaaldrich.com/catalog/product/sial/ 56678 ? lang $=$ en\& region $=I D$

Syarovy. M. (2013). Unsur hara makro dan mikro (Esensial). http://www.eratani.com/unsur-haramakro-dan-mikro-esensial/.

Wulandari, A. (2000). Evaluasi Nilai Nutrisi Tepung Silase Ikan dengan Metoda Kimiawi dan Bahan Pengikat Dedak Padi dan Pollard. Thesis. IImu nutrisi dan makanan ternak. Fakultas Peternakan. Institut Pertanian Bogor. $53 \mathrm{p}$.

Yunizal, Murtini, J.T., Dolaria, N., Purdiwoto, B., Rokhim, A., \& Carkipan. (1998). Prosedur Analisa Kimiawi Ikan dan Produk Olahan Hasil-Hasil Perikanan. Instalasi Penelitian Perikanan Laut Slipi. Balai Penelitian Perikanan Laut, Pusat Penelitian dan Pengembangan Perikanan Jakarta. 100 p. 